\begin{tabular}{|c|l|}
\hline Title & $\begin{array}{l}\text { Soft gel medium solidified with gellan gum for preliminary screening for root-associating, free living nitrogen-fixing } \\
\text { bacteria inhabiting the rhizoplane of plants }\end{array}$ \\
\hline Author(s) & Hashidoko, Y asuy uki; Tada, Motohiko; Osaki, Mitsuru; Tahara, Satoshi \\
\hline Citation & $\begin{array}{l}\text { Bioscience Biotechnology and Biochemistry, 66(10), 2259-2263 } \\
\text { https://doi.org/10.1271/bbb.66.2259 }\end{array}$ \\
\hline Issue Date & 2002-10 \\
\hline Doc URL & http://hdl.handle.net/2115/15846 \\
\hline Type & article \\
\hline File Information & BB\&B66-10.pdf \\
\hline
\end{tabular}

Instructions for use 
Note

\title{
Soft Gel Medium Solidified with Gellan Gum for Preliminary Screening for Root-associating, Free-living Nitrogen-fixing Bacteria Inhabiting the Rhizoplane of Plants
}

\author{
Yasuyuki Hashidoko,,${ }^{1} \uparrow$ Motohiko TAda, ${ }^{1}$ Mitsuru Osaki,${ }^{2}$ and Satoshi TAHARA ${ }^{1}$ \\ ${ }^{1}$ Division of Applied Bioscience, Graduate School of Agriculture, Hokkaido University, Kita-ku, \\ Sapporo 060-8589, Japan \\ ${ }^{2}$ Division of Bioresources and Product Science, Graduate School of Agriculture, Hokkaido, Kita-ku, \\ Sapporo 060-8589, Japan
}

Received April 4, 2002; Accepted June 18, 2002

\begin{abstract}
For preliminary screening for and characterization of free-living nitrogen-fixing bacteria from rhizoplane microflora, we used Winogradsky's mineral mixturebased nitrogen-free medium solidified with $0.3 \%$ gellan gum. The soft gel medium enabled some reference and wild free-living nitrogen-fixing bacteria to grow in characteristic colonies, including their reaction to oxygen and their motility change. Gellan gum is thus likely to be a better gel matrix than agarose for the investigation of root-associating, free-living nitrogen-fixing bacteria to identify their characteristic behaviors.
\end{abstract}

Key words: free-living nitrogen-fixing bacterium; gellan gum; Plantago lanceolata; rhizoplane microflora

Soft gel media solidified with $0.5 \%$ agarose are widely used in identification of bacteria to discover their respiratory type. ${ }^{1)}$ In the soft gel media, both non-motile and motile bacteria are caught by the gel matrix and immobilized, and accordingly, the bacteria when stab-cultured display characteristic emergence of their colonies in certain depths of the soft gel medium from the top, depending on their reaction to dissolving oxygen. Applied this manner, soft gel media have been used for selective detection and screening of free-living nitrogen-fixing bacteria. Dobereiner and her group first used soft gel media, in which a nitrogen-free salt mixture plus saccharose (or malic acid) as a sole carbon source was solidified with $0.2 \%$ agarose. ${ }^{2)}$ Using the soft gel medium, they isolated some endophytic and/or epiphytic, nitrogenfixing bacteria, particularly from the rhizoplane of monocotyledonous crop plants. ${ }^{3,4)}$ To date, this soft gel technique is widely used as the most basic culture method for screening of root-associating, nitrogenfixing bacteria, although microbiologists are still groping for another simple method.5) Agarose with relatively low turbidity, however, often prevented observation of thin or blurred colonies over the glass wall of the test tubes. Namely, the slight turbidity of the $0.2 \%$ agarose medium often led to failure in detection of bacteria that have high motility or form highly transparent colonies in the gel. To avoid this problem in the agarose-base soft gel medium, we replaced $0.2 \%$ agarose with $0.3 \%$ gellan gum, which is a polysaccharide originally produced by a bacterium, Pseudomonas elodea. ${ }^{6,7)}$

Winogradsky's nitrogen-free mineral medium, originally developed for Azotobactor, was prepared with the following composition: ${ }^{8)} \mathrm{KH}_{2} \mathrm{PO}_{4}, 50.0$ (g / ); $\mathrm{MgSO}_{4} \cdot 7 \mathrm{H}_{2} \mathrm{O}, 25.0 ; \mathrm{NaCl}, 25.0 ; \mathrm{FeSO}_{4} \cdot 7 \mathrm{H}_{2} \mathrm{O}$, 1.0; $\mathrm{Na}_{2} \mathrm{MoO}_{4} \cdot 2 \mathrm{H}_{2} \mathrm{O}, 1.0 ; \mathrm{MnSO}_{4} \cdot 4 \mathrm{H}_{2} \mathrm{O}, 1.0$; and $\mathrm{NaOH}$ to adjust the $\mathrm{pH}$ to 7.2 . To $1000 \mathrm{ml}$ of a sugar (saccharose or mannitol, $10 \mathrm{~g}$ ) and $\mathrm{CaCO}_{3}$ (powdery type, $0.1 \mathrm{~g}$ ) solution, $5 \mathrm{ml}$ of the mineral mixed solution was added, adjusted its $\mathrm{pH}$ to 6.2 with $2 \mathrm{M}$ $\mathrm{H}_{2} \mathrm{SO}_{4}$, and then filtered with a hydrophilic polytetrafluoroethylene membrane $(0.45 \mu \mathrm{m}$, Millipore $)$. To the resulting filtrate, $0.3 \% \mathrm{w} / \mathrm{v}$ of gellan gum powders (Kanto Chemical Co.) were added and then heated to dissolve the polysaccharide completely. In general, 5 or $10 \mathrm{ml}$ of the gellan-gum-containing medium was poured into a test tube of $16 \mathrm{~mm}$ inner diameter, plugged with a siliconized polymer sponge, and then autoclaved at $120^{\circ} \mathrm{C}$ for $20 \mathrm{~min}$. After this cooled down, $100 \mu \mathrm{l}$ of a root washing prepared from a plant was added to the liquefied medium under aseptic conditions, vortexed well to remove drops condensed on the inner glass wall, and incubated at $20^{\circ} \mathrm{C}$

Gellan gum, a nitrogen-free polysaccharide, is highly transparent, even at $1.2 \%$ concentration. Moreover, the nitrogen-free media solidified with $0.3 \%$ gellan gum are harder than $0.2 \%$ agarose, so that bacterial cells only slightly motile are visible as a balloon-like swarming colony due to being trapped by the gel matrix. Another advantage of the gellan

† To whom correspondence should be addressed. Tel: +81-11-706-3839; Fax: +81-11-706-4182; E-mail: yasu-h@abs.agr.hokudai.ac.jp 
A

B
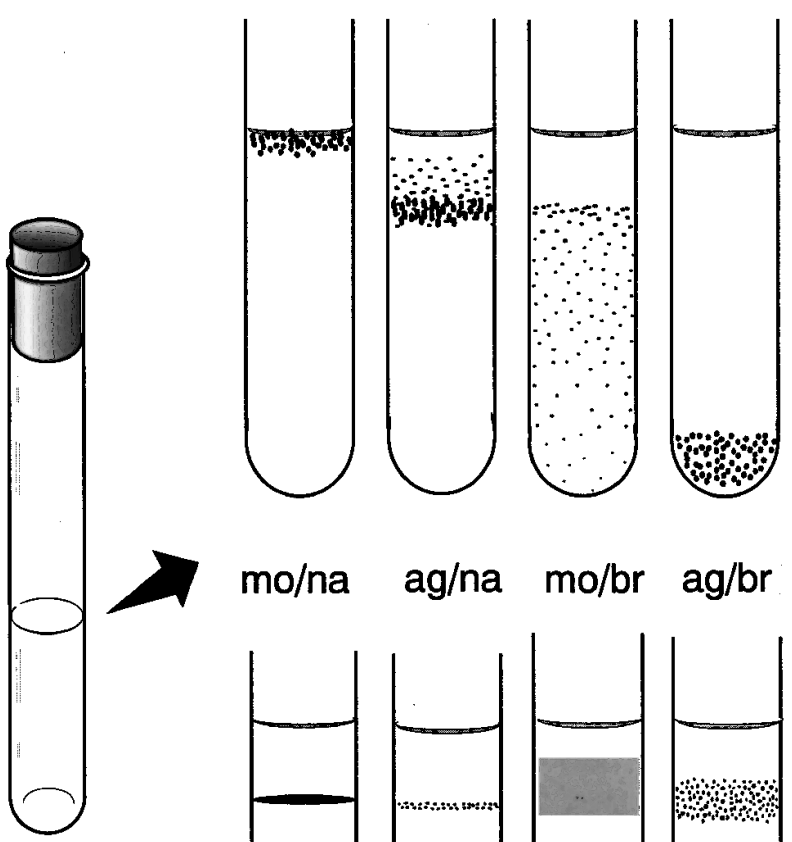

$\mathrm{mo} / \mathrm{na}$

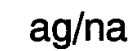

$\mathrm{mo} / \mathrm{br}$
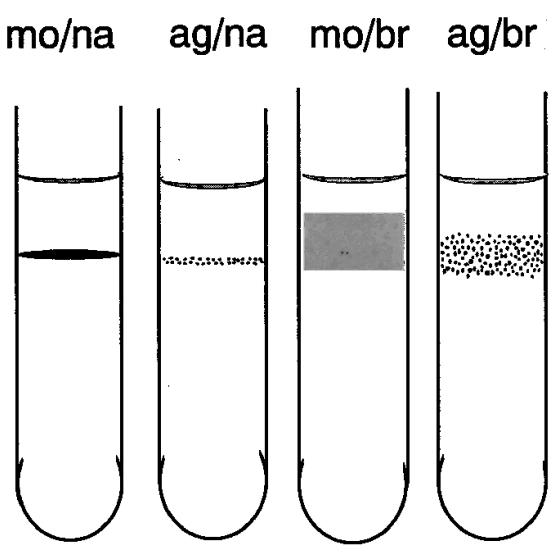

Fig. 1. Four Basic Patterns of Colony Emergence in Soft Gel Medium Solidified with $0.3 \%$ Gellan Gum.

Patterns of colony emergence reflect their respiratory type as follows: A) aerobes, B) micro-aerobes, C) facultative anaerobes and D) aero-tolerant anaerobes. In addition, their adaptability and reaction to dissolving oxygen are represented as narrow (shown as na) or broad (br), and motility of the bacteria as motile (mo) or non-motile /aggregative (ag).

gum media is its liquefactive nature. When the $0.3 \%$ gellan gum medium was autoclaved and left to cool to room temperature, the liquefactive medium slowly solidified, unlike the $0.2 \%$ agarose. The gellan gum medium maintained its liquefied form at least for $3 \mathrm{~h}$, and often overnight, after the autoclaved medium was cooled down. Because of this nature, it is possible to vortex nitrogen-free mineral media solidified with $0.3 \%$ gellan gum at room temperature, making it easy to disperse any bacterial inoculum uniformly. Due to such benefits described above, the soft gel media solidified with $0.3 \%$ gellan gum are applicable to field investigation for qualitative analysis of nitrogen-fixing bacteria inhabiting on plant rhizoplane.

We used two reference bacteria, Klebsiella pneumoniae IFO $3318^{9)}$ and Beijerinckia indica subsp. indica IFO $3744,{ }^{10}$ and in parallel, we allowed several wild isolates or a bacterial mixture to grow in the gellan gum medium. Several patterns of the colony emergence of the bacteria tested so far were ob- served, and we grouped the patterns according to their reaction to dissolving oxygen and their cell motility, as illustrated in Fig. 1. K. pneumoniae IFO 3318 , a non-motile, facultative anaerobe of sub-division $\gamma$-proteobacteria, clustered in aggregations of whitish granular colonies throughout the medium spreading from the bottom to a certain depth (Fig. 2). On the other hand, B. indica subsp. indica IFO 3744, a non-motile aerobe of sub-division $\alpha$ proteobacteria, formed dense aggregates of a half transparent, tiny disk colony near the top surface of the medium. Both of the bacteria showed the most typical patterns of each reaction to oxygen, when approximately $10^{3}-10^{4}$ cells were inoculated in $10 \mathrm{ml}$ of the medium (data not shown). When these bacteria were cultured in mixture after uniform inoculation, they independently displayed each of characteristic patterns in the colony emergence that had been observed by single inoculation of each.

To demonstrate the advantage of gellan gum medium in screening of wild free-living nitrogen-fixing bacteria, we investigated the rhizoplane of Plantago lanceolata. A rosette of $P$. lanceolata, known as a plant tolerant of sandy soil and capable of assimilating nitrogen sources actively from the roots, ${ }^{11)}$ was sampled at the Shinkawa estuary area at Ishikari Bay, and its root system was washed with a large volume of clean water to remove the sandy soil around the root surface. The resulting fine root, cut by clean scissors into pieces $5 \mathrm{~cm}$ in length, was then slowly shaken in 10-20 $\mathrm{ml}$ of sterile water repeatedly to rinse out the remaining soil. The root tissue thus cleaned was vortexed in $20 \mathrm{ml}$ of sterile water for 10 seconds in a sterile $50 \mathrm{ml}$-Falcon polypropylene tube and left for $10 \mathrm{~min}$, at which time the supernatant was used as an original inoculum from the rhizoplane. The bacterium was isolated on agar plates of a modified Winogradsky's mineral mixture containing $0.005 \%$ yeast extract and $1 \%$ saccharose. The bacterial colonies emerging on the plate as the first major (colorless, transparent, sticky, and domelike) and the second major (whitish, half-transparent, mucilaginous, and flat) colonies were purified on the modified Winogradsky's agar plate. The emergence frequency of these isolates was approximately 40 and $30 \%$, respectively. The resulting two wild isolates, subsequently confirmed in their ability to grow on the agar plate without yeast extract ('completely $\mathrm{N}$-free medium'), were stab-cultured in soft gel media, which was Winogradsky's mineral medium ( $\mathrm{pH}$ 6.2) containing $1 \%$ mannitol and $20 \mathrm{mg} / \mathrm{l}$ bromothymol blue as a carbon source and a $\mathrm{pH}$ indicator, respectively, was solidified with $0.2 \%$ agarose or $0.3 \%$ gellan gum.

The first major isolate, tentatively identified as Zoogloea ramigera of subdivision $\alpha$-proteobacteria by a partial analysis of $16 \mathrm{~S}$ rDNA sequences, ${ }^{12)}$ formed in its pure culture an elastic, mucilaginous, 
K. pneumoniae

\section{K. pneumoniae}

\section{$+$}

B. indica subsp. indica

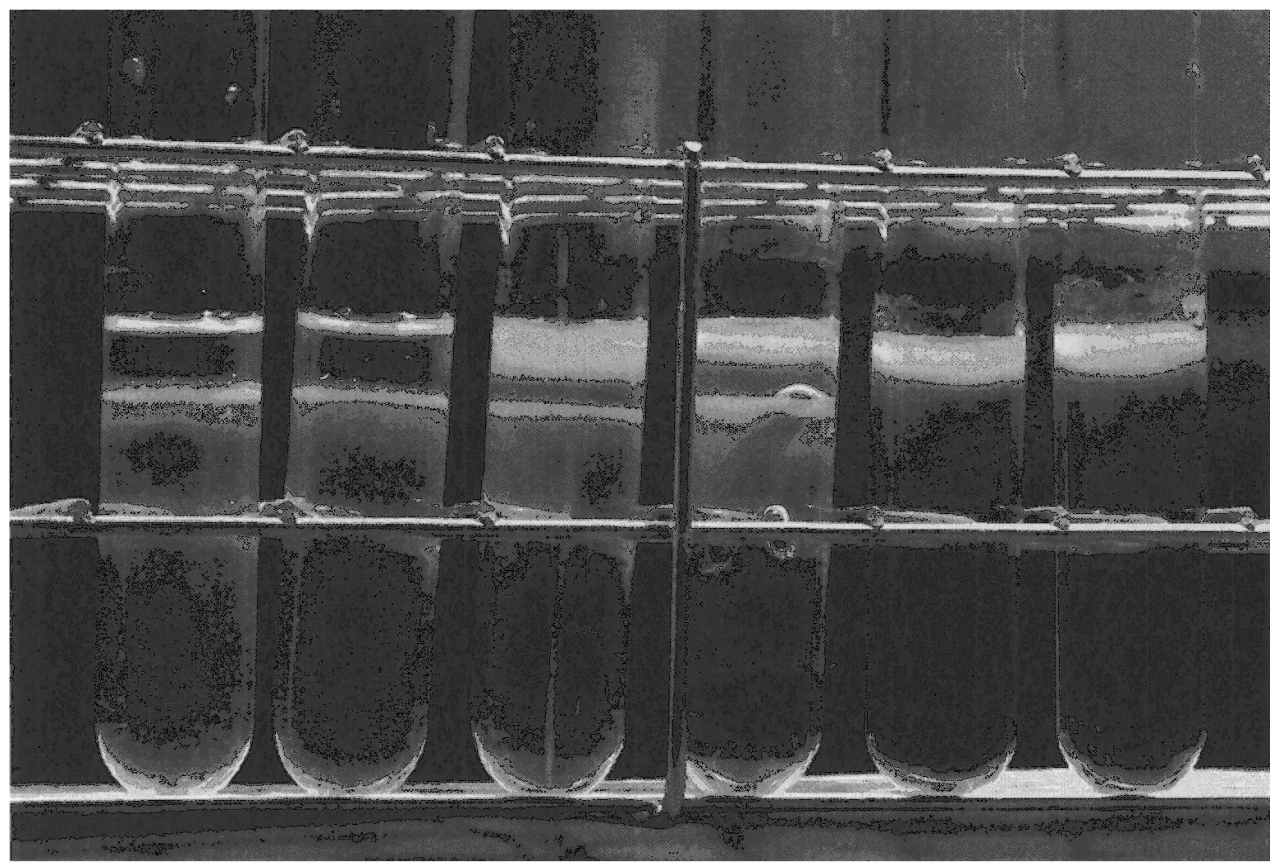

\section{$1 \times 10^{5} \quad 1 \times 10^{5}+1 \times 10^{5} \quad 1 \times 10^{5}$}

Fig. 2. Combined Patterns of Colony Emergence of K. pneumoniae IFO 3318 and B. indica subsp. indica IFO 3744 .

Right: bacterial suspensions of $K$. pneumoniae IFO 3318 with $10^{5}$ cells were used to inoculate the soft gel medium. Mid: bacterial suspension of $B$. indica subsp. indica IFO $3744\left(10^{5}\right.$ cells $)$ and $K$. pneumoniae IFO 3318 (10 5 cells) were used to inoculate the soft gel media at the same time. Left: $B$. indica subsp. indica IFO 3744 with $10^{5}$ cells. The tubes were incubated for 3 weeks at $20^{\circ} \mathrm{C}$ in the dark. In the gellan gum medium, the colony emergence of each bacterium reflected reaction to dissolving oxygen typical of facultative anaerobes and obligate aerobes, respectively. In the mixed cultures, both of the bacteria maintained their own characteristic pattern of each colony emergence in one tube.

semi-turbid, round colonies on the modified Winogradsky's mineral agar plate. Cell of the isolate aggregated in any liquid medium in which it grew, so we judged that the isolate usually had no motility. In the gellan gum medium, the isolate grew in semiturbid, swollen balloons-like colonies with a pattern of facultative anaerobes along the stabbing slit line, ${ }^{1)}$ but colonies emerged from the bottom to the top and formed a micro-aerobe-like dense region at a certain depth (B/C in Fig. 1) when the cell suspension was used to uniformly inoculate the soft gel medium (uniform culture). Similar colony development was visible during stab-culture in the $0.2 \%$ agarose medium; however, the bacterial colony diffused into the medium within several days (Fig. 3).

The second major isolate, tentatively identified as a Caulobacter sp. of subdivision $\alpha$-proteobacteria, formed a transparent, round colony with a large amount of mucilage production in its pure culture on the modified Winogradsky's agar plate. It formed a layer at a certain depth of the soft gel medium to dis- perse the colony horizontally, both in the stab-culture and the uniform culture. The highly motile and micro-aerobic natures of the bacterium allowed it to spread along the appropriate oxygen concentration, forming a bacterial layer in the gellan gum medium. Due to the turbidity of the agarose medium, such a thin layer was hardly observed in the $0.2 \%$ agarose medium (Fig. 3).

When two isolates were stabbed in one tube of the gellan gum medium for double-inoculation, both showed characteristic behaviors during colony emergence. Interestingly, $Z$. ramigera did not cluster in aggregates along the stabbing slit but did show much rapid dispersal from the slit line into the gellan gum medium, probably due to its chemotactic response ${ }^{13)}$ to unknown chemical substance produced by Caulobacter sp. that activated its motility. Such a physiological response of the bacteria in the mixed culture, visible as a change of colony development in the gellan gum medium, suggests close interactions between or amongst rhizoplane microflora of the 


\section{Stab-culture of Z. ramigera}

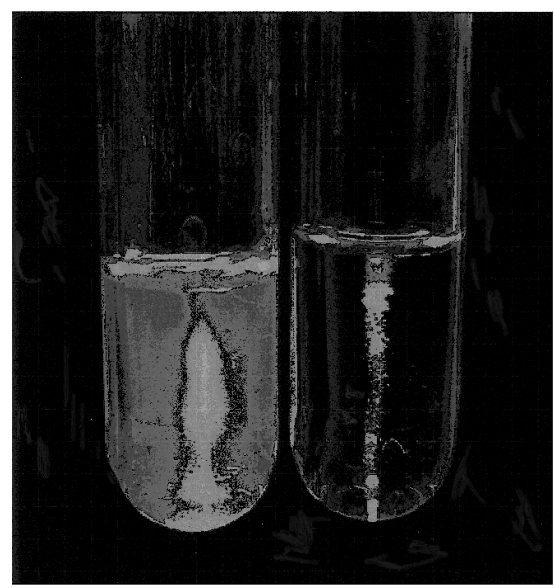

\section{$0.2 \%$ Agarose Gellan gum}

\section{Stabbing mixed culture of Z. ramigera + Caulobacter sp.}
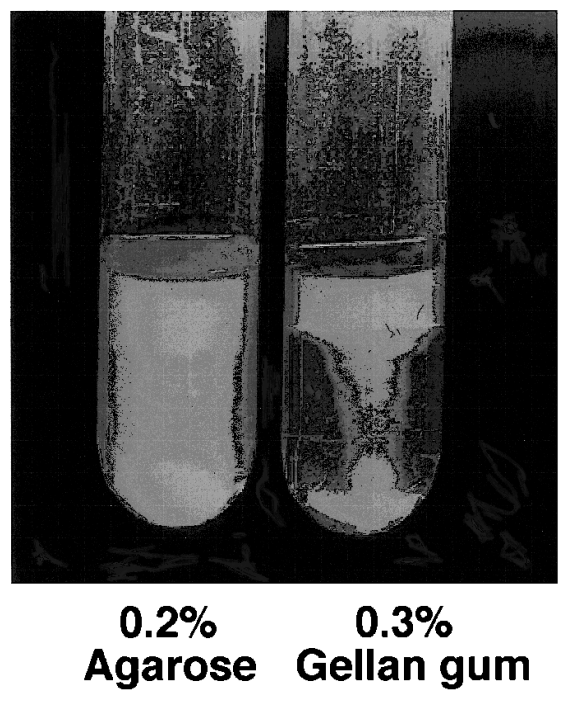

\section{Stab-culture of Caulobacter sp.}

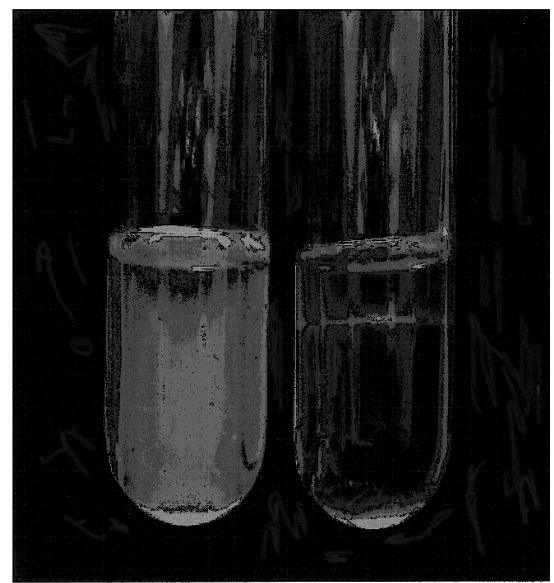

\section{$0.2 \%$ Agarose Gellan gum}

Fig. 3. Appearance of Bacterial Colonies in $0.3 \%$ Gellan Gum Medium and in $0.2 \%$ Agarose, and Effect of Mixed Culture on Alternative Chemotactic Response of the Less Motile Bacterium in Single Culture.

Nitrogen-free medium with $1 \%$ mannitol was solidified with $0.3 \%$ gellan gum or $0.2 \%$ agarose and the wild isolates were stab-cultured. The loop was stabbed twice into the medium for the pure culture, or each isolate was stabbed separately once for mixed culture. After the inoculation, tubes were kept at $20^{\circ} \mathrm{C}$ in the dark. At 2 days of incubation, thin but clear colonies of isolates was clear in $0.3 \%$ gellan gum medium, but was indistinct in $0.2 \%$ agarose medium. The motile isolate, Caulobacter sp., started to form a horizontal ringlike layer at this stage. At 1 week of incubation, $Z$. ramigera appeared as thick colonies along the stabbing slit in the gellan gum medium, but its whitish colonies in the mixed culture in gellan gum medium looked hazy and were dispersed into the medium. After 2 weeks, $Z$. ramigera in the mixed culture was cylindrically and uniformly dispersed throughout the medium. Tentative identification of these bacteria were done by means of PCR of each 16R rDNA region with the universal forward (5F or 357F) and reverse (1080R or $1540 \mathrm{R})$ primers under reaction conditions as follows: 35 cycles of $94^{\circ} \mathrm{C}$ for $30 \mathrm{~s}, 55^{\circ} \mathrm{C}$ for $1 \mathrm{~min}$ and $72^{\circ} \mathrm{C}$ for $1 \mathrm{~min}$. [DDBJ accession $\mathrm{No}$.; AB086018 and AB086019 for Z. ramigera and Caulobacter sp. isolated from P. lanceolata rhizoplane, respectively]

host plant as known in some bacterial species. ${ }^{14,15)}$ Thus, the nitrogen-free medium solidified with $0.3 \%$ gellan gum will be a convenient tool for studies of rhizoplane bacteria, which expresses complex physiological actions and behaviors.

In field studies of free-living nitrogen fixing bacteria inhabiting the rhizosphere and/or rhizoplane of host plants, a rapid and easy screening method is often required in collection and evaluation of microfloral components. The gellan gum-base soft gel medium is likely to be beneficial in field investigations in particular, because it can be used to screen bacteria for that grow in $\mathrm{N}$-free medium. The soft gel method is for preliminary investigation for freeliving nitrogen fixers, because nitrogen fixation must be proven by the acetylene reduction method or nif gene detection by molecular biological techniques. In terms of bacterial growth, gellan gum is used as a gel matrix for selective isolation of Planobispora, ${ }^{16)}$ and it is also an appropriate medium for several microorganisms to use for PCR. ${ }^{17)}$ As another gelling material, isubgol, the mucilaginous husk from the seeds of $P$. ovata, is also used in a culture medium for Rhizobium meliloti, and the gelling medium has promoted the bacterial growth. ${ }^{18)}$ These reports suggest the usefulness of alternative soft gel media for culturing nitrogen-fixing bacteria. Our approach to evaluate rhizoplane bacteria in the gellan gum-made soft gel media may lead to revealing tight partnerships between host rhizoplane and root-associating bacteria or between free-living nitrogen-fixing bacteria and other bacteria composing rhizoplane microflora.

\section{Acknowledgments}

We thank Dr. Tadashi Yoshida for his information about handling bacteria.

\section{References}

1) Sneath, P. H. A., Classification of microorganisms. In "Norris and Richmond Essays in Microbiology", John Wiley, Chichester, UK, pp. 9/1-9/31 (1978).

2) Dobereiner, J., Isolation and identification of aerobic nitrogen-fixing bacteria from soil and plants. In "Methods in Applied Soil Microbiology and Biochemistry", eds. Alef, K., and Nannipieri, P., Academic Press, London, pp. 134-141 (1995).

3) Rainhold, B., Hurek, T., Fendrik, I., Pot, M., Gillis, M., Kersters, K., Thielemans, D., and De Ley, J., Azospirillum halopraeferans sp. nov., a nitrogen 
fixing organism associated with roots of Kallar grass (Leptochloa fusca (L.) Kunth). Int. J. System. Bacteriol., 37, 43-51 (1987).

4) Baldani, J. I., Caruso, L., Baldani, V. L. D., Goi, S. R., and Dobereiner, J., Recent advances in BNF with non-legume plants. Soil Biol. Biochem., 29, 911-922 (1997).

5) Tran, V. V., Ngoke, S., Berge, O., Faure, D., Bally, R., Hebbar, P., and Heulin, T., Isolation of Azospirillum lipoferum from the rhizosphere of rice by a new, simple method. Can. J. Microbiol., 43, 486-490 (1997).

6) Kang, K. S., and Veeder, G. T., Polysaccharide S-60 and bacterial fermentation process for its preparation. U.S. Patent 4377636 (March 22, 1983).

7) Moorhouse, R., Structure/property relationships of a family of microbial polysaccharides. In "Industrial Polysaccharides: Genetic Engineering, Structure/ Property Relations and Applications, Progress in Biotechnology, Vol. 3"', ed. Yalpani, M., Elsevier, Amsterdam, pp. 187-206 (1987).

8) Tchan, Y.-T., and New, P. B., Genus 1. Azotobacter Beijerinck 1907, 567. AL In “Bergey's Manual of Systematic Bacteriology”, $8^{\text {th }}$ Ed., Vol. 1, ed. Krieg, N. R., and Holt, J. G., Williams \& Wilkins Co., Baltimore, pp. 220-229 (1984).

9) Orskov, I., Genus 5. Klebsiella Trevisan 1885, 105. $\mathrm{AL}$ In 'Bergey's Manual of Systematic Bacteriology", $8^{\text {th }}$ Ed., Vol. 1, eds. Krieg, N. R., and Holt, J. G., Williams \& Wilkins Co., Baltimore, pp. 461-465 (1984).

10) Becking, J.-H., Genus Beijerinckia Derx 1950, $145^{\mathrm{AL}}$ In 'Bergey's Manual of Systematic Bacteriology", $8^{\text {th }}$ Ed., Vol. 1, eds. Krieg, N. R., and Holt, J. G., Williams \& Wilkins Co., Baltimore, pp. 311-321
(1984).

11) Verhagen, F. J. M., Laanbroek, H. J., and Woldendrop, J. W., Competition for ammonium between plant roots and nitrifying and heterotrophic bacteria and the effects of protozoan grazing. Plant Soil, 170, 241-250 (1995).

12) Weisburg, W. G., Barns, S. M., Pelletier, D. A., and Lane, D. J., 16S ribosonal DNA amplification for phylogenetic study. J. Bacteriol., 173, 697-703 (1991).

13) Shah, D. S. H., Porter, S. L., Harris, D. C., Wadhams, G. H., Hamblin, P. A., and Armitage, J. P., Identification of a fourth che $Y$ gene in Rhodobacter sphaeroides and interspecies interaction within the bacterial chemotaxis signal transduction pathway. Mol. Microbiol., 35, 101-112 (2000).

14) Alexandre, G., Jacoud, C., Faure, D., and Bally, R., Population dynamics of a motile and a non-motile Azospirillum lipoferum strain during rice root colonization and motility variation in the rhizosphere. FEMS Microbiol. Ecol., 19, 271-278 (1996).

15) James, E. K., Nitrogen fixation in endophytic and associative symbiosis. Field Crop Res., 65, 197-209 (2000).

16) Suzuki, S., Okuda, T., and Komatsubara, S., Selective isolation and study on the global distribution of the genus Planobispora in soils. Can. J. Microbiol., 47, 979-986 (2001).

17) Rath, P. M., and Schmidt, D., Gellan gum as a suitable gelling agent in microbiological media for PCR applications. J. Med. Microbiol., 50, 108-109 (2001).

18) Jain, N., Gupta, S., and Babbar, S. B., Isubgol as an alternative gelling agent for microbial culture media. J. Plant Biochem. Biotechnol., 6, 129-131 (1997). 